\title{
Email Forwardables: Characterizing the Teacher Community in Brazil
}

Correos electrónicos reenviables: Caracterización de la comunidad docente en Brasil

Courriers electroniques renvoyes : Caracterisation de la communaute des enseignants au Bresil

Correios eletrônicos reenviáveis: Caracterização da comunidade docente no Brasil

\begin{abstract}
In this article, we analyze four of twelve forwardables, that is, email messages, received over a period of four months with the objective of comprehending the discourses about teachers and the teaching profession which pervade the teachers' cultural space in Brazil. For the purpose of analyzing these forwardables, we combine the concept of cultural domain (Spradley, 1980) and the methodological principles of critical discourse analysis (Fairclough, 2010). Our analyses show another aspect of group identity besides that of professional activities, which is a sense of occupying a place of low social prestige. The forwardables, therefore, by being sent on from teacher to teacher in a continuous chain become a form of social cohesion of this particular group.
\end{abstract}

\section{Key words plus}

Email Forwardables, Teachers, Group Identity.

\section{Transfer to practice}

Based on our analysis and considering forwardables as cultural artifacts rooted in discourse, we believe that this article might contribute to valuing the cultural meanings that Brazilian teachers have given to their practice, and consequently to promoting critical discussions regarding the problems which surround the teaching profession in Brazil. Likewise, we believe that our reflections might encourage Brazilian teachers who work in different contexts to critically examine their situation, to discuss it with their colleagues and with their students, and finally to look for new and more effective ways to reinvent their practice and their social/cultural position.

To cite this article / Para citar este artículo / Pour citer cet article / Para citar este artigo

Rees, D. K. \& Urzêda-Freitas, M. T. (2015). Email Forwardables: Characterizing the Teacher Community in Brazil. magis, Revista Internacional de Investigación en Educación, 7 (15), 81-96. 
Palabras clave descriptor

Correos electrónicos reenviados,

maestros, identidad de grupo.

\section{Resumen}

En este artículo se analizan cuatro de doce mensajes reenviables, es decir, correos electrónicos recibidos durante un período de cuatro meses, con el objetivo de comprender los discursos sobre los docentes y la profesión docente que prevalecen en el espacio cultural de los profesores en Brasil. Para analizar estos mensajes reenviados, combinamos el concepto de ámbito cultural (Spradley, 1980) con los principios metodológicos del análisis crítico del discurso (Fairclough, 2010). Nuestro análisis muestra otro aspecto de la identidad de grupo, además del relacionado con las actividades profesionales, que tiene que ver con la sensación de ocupar un lugar de bajo prestigio social. Los mensajes, por tanto, al ser enviados de maestro a maestro en una cadena continua se convierten en una forma de cohesión social de este grupo en particular

\section{Transferencia a la práctica}

Sobre la base de nuestro análisis y considerando los mensajes reenviados como artefactos culturales arraigados en el discurso, este artículo podría contribuir a la valoración de los significados culturales que los profesores brasileños han dado a su práctica y, por tanto, a la promoción de debates críticos sobre los problemas que rodean la profesión docente en Brasil. Del mismo modo, nuestras reflexiones podrían animar a los profesores brasileños que trabajan en diferentes contextos a examinar críticamente su situación, para discutirla con sus colegas y con sus alumnos y, finalmente, animarlos a buscar nuevas y más efectivas formas de reinventar su práctica y su posición social/cultural.
Mots clés descripteur

Courriers électroniques renvoyés, enseignants, identité de groupe.

\section{Résumé}

Dans cet article on analyse quatre parmi douce messages renvoyés, c'est-à-dire, courriers électroniques, reçus pendant une période de quatre mois avec l'objectif de comprendre les paroles sur les enseignants et la profession d'enseignant qu'on a dans I'espace culturel des enseignants au Brésil. Avec l'objectif d'analyser ces messages renvoyés, on articule le concept de domaine culturel (Spradley, 1980) et les principes méthodologiques de I'analyse critique du discours (Fairclough, 2010). Notre analyse montre un autre aspect de l'identité de groupe, en plus de celui qui concerne les activités professionnelles, il s'agit de la sensation d'occuper un lieu de peu prestige sociale. Puisque les messages sont envoyés d'un enseignant à un autre enseignant dans une chaine continue ces messages se transforment dans une forme de cohésion sociale de ce groupe en particulier.

\section{Transfert à la pratique}

Sur la base de notre analyse et en considérant les messages en tant qu'artefacts culturels enracinés dans le discours, on croit que cet article pourrait contribuer à la mise en valeur des signifiants culturels que les enseignants brésiliens ont donné à sa pratique, et donc à la promotion de débats critiques sur les problèmes qui entourent à la profession d'enseignant au Brésil. Ainsi, on croit que nos réflexions pourraient animer aux enseignants brésiliens à travailler dans les différents contextes et à examiner d'une manière critique leur situation, pour en discuter avec leurs collègues et avec leurs élèves, et enfin les animer pour chercher d'autres façons plus effectives de réinventer leur pratique et leur position sociale/culturelle.

\section{Palavras-chave descritor}

Correios eletrônicos reenviados, mestres, identidade de grupo.

\section{Resumo}

Neste artigo analisam-se quatro das doze mensagens reenviáveis, isto é, correios eletrônicos, recebidos durante um período de quatro meses com o objetivo de compreender os discursos sobre os docentes e a profissão docente que prevalecem no espaço cultural dos professores no Brasil. Com o fim de analisar estas mensagens reenviadas, combinamos o conceito de âmbito cultural (Spradley, 1980) e os princípios metodológicos da análise crítica do discurso (Fairclough, 2010). Nossa análise mostra outro aspecto da identidade de grupo, além do relacionado com as atividades profissionais, que tem a ver com a sensação de ocupar um lugar de baixo prestígio social. As mensagens, portanto, ao ser enviadas de professor a professor em uma corrente contínua se tornam uma forma de coesão social deste grupo em particular.

\section{Transferência à prática}

Sobre a base de nossa análise e considerando as mensagens reenviadas como artefatos culturais arraigados no discurso, achamos que este artigo poderia contribuir à valorização dos significados culturais que os professores brasileiros têm dado a sua prática e, portanto, à promoção de debates críticos sobre os problemas que rodeiam à profissão docente no Brasil. Do mesmo modo, achamos que nossas reflexões poderiam animar aos professores brasileiros que trabalham em diferentes contextos a examinar criticamente sua situação, para discutir com seus colegas e com seus alunos, e finalmente, animá-los a procurar novas e mais efetivas formas de reinventar sua prática e sua posição social/cultural. 


\section{Introduction}

In Brazil as elsewhere in the world email has become a central form of communication both at a personal level and at business and work related levels. This fact has sparked studies ranging from a discussion of the specific form and language of emails as a new textual genre (Marcuschi \& Xavier, 2005), through studies of the legal nature of emails (Calvo, 2001), to proposals by teachers regarding the use of emailing as a means of enhancing foreign language learning (Carvalho, 2010; Paiva, 2001; Souza, 2005).

As a background to the fact that emailing is a part of everyday Brazilian life for many, it is necessary, however, to mention the important study entitled Digital Exclusion Map (Mapa da Exclusão Digital, 2003) undertaken for the National Bank for Economic and Social Development (BNDES) and which pointed out that the number of people who had computers in their homes was 16.209 .223 .00 , approximately $10 \%$, out of a total population of 169.872 .850 (p. 60). On a positive note, according to the Digital Inclusion clock created by the NGO Democratization of Computer Access (CDI - Democratização da Informática) every trimester a million new users are digitally included through various government and NGO programs. As reported by the Brazilian Institute of Geography and Statistics (IBGE - Instituto Brasileiro de Geografia e Estatística - http://www.ibge.gov.br/home/), in 2011 31.2\% of Brazilian homes had a computer and $23.8 \%$ had internet access. Thus though many more homes have computers since the study by BNDES was concluded, this article in its focus on email forwardables is consequently discussing what takes place amongst a group of the digitally included, and not discussing Brazilians as a nationwide group.

The reason that we are interested in forwardables about teachers is that we work with foreign language teaching and research at the Universidade Federal de Goiás, in Goiânia, Brazil. It is a public university, funded by the Federal Government, and is one of the major universities within the Middle West region of Brazil. It has a total of 13.825 students. The Letras course has 415 students. The first author teaches and researches in the Letras: Licenciatura course which prepares students to be accredited teachers of Portuguese, English, Spanish or French, depending on their choice of Major; she works in the English language Major. In his turn, the second author teaches English and researches about language education in the Centro de Línguas (Language Center), an extension project of the Faculdade de Letras which has currently more than 2.000 students.

The forwardables that are the focus of this article were received over a period of four months, September to December 2011. At first, they were received spontaneously, but after noticing how the topic of these emails was the identity of the teacher in Brazilian society, emails were sent out to a list of students and colleagues asking that they forward any messages that focused on teachers. It was noticed that the same messages were received over and over again from various different senders, an indication that the same forwardables were making the rounds at least within the local social group consisting of teachers or future teachers associated with the Faculdade de Letras of the Universidade Federal de Goiás. This constant receiving of the same forwardables created an interest in understanding how these messages were expressing the cultural identity of the Brazilian teacher and how they were inserted in certain discursive practices. Thus throughout the text, we will be discussing how these forwardables contribute to the creating of the identity of Brazilian education professionals. In this article, the term identity "refers specifically to those aspects of a person that are defined in terms of his or her group memberships" (Deaux, 2001, p. 1).

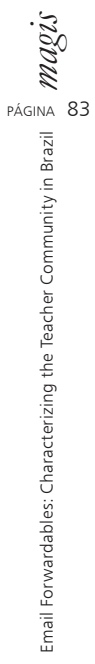

Article description | Descripción del artículo | Description de l'article | Artigo descrição

The article analyzes cultural artifacts rooted in discourse, and through the discussion of cultural domains and critical discourse analysis, shows an aspect of the group identity for teachers that goes beyond that of professional activities, describing them as occupying a place of low social prestige. 


\section{The Situation of the Teaching Profession in Brazil}

The teaching profession is going through a crisis in Brazil. As reported to the Ministry of Education, there is a deficit of 246.000 teachers (MEC, 2008) considering all levels of education. The greatest need is for math, physics and chemistry teachers at the secondary level. In addition, the Ministry of Education is worried about the average age of the teaching professional which is between 40 and 50 years of age. This means that young people are not seeking out this profession and that within twenty years, there will be an even greater lack of teachers.

According to the report, The Attractiveness of the Teaching Profession in Brazil (Atratividade da Carreira Docente no Brasil), made by the request of the Carlos Chagas Foundation, and coordinated by researcher Bernadete Gatti, the social prestige of this profession has diminished over the last decades and has resulted in a gap between the ideal definition of teaching and the reality of being a teacher. This gap, in turn, leads to feelings of powerlessness, frustration, and discouragement (Gatti, 2009, p. 12). The causes of this gap and the resulting lack of social prestige are many. One is the change in modern society in which the school is no longer the only place which offers access to knowledge and to social and economic progress (p. 12). Another cause is the fact that in Brazilian society, there are lay-teachers, that is, teachers who have not been through a university teaching certificate course. The result is that there tends to be an attitude that anyone can be a teacher, thus for example, an Engineering student that knows some English will pick up some classes to teach in order to pay the way through college. This type of teacher knows nothing about Applied Linguistics, Methodology or the research in Second Language Acquisition which are all topics that a student learns in the university teaching certificate course.

In addition, when researchers focused on the student body at universities, it was shown that the students of the teaching certificate courses came from less privileged social classes than those in the more prestigious courses such as Medicine and Law (DinizPereira, 2011, p. 41). The teaching certificate students were older as they took longer to get into university after High School and came in greater number from the public school system rather than from private schools. They were also working students that had to hold down jobs at the same time they were going through university. Many of these students chose the teaching certificate course because the cut-off grade on the university entrance exam was lower for these courses than for other more prestigious courses. This cut-off grade is calculated considering the number of candidates per student place. In the teaching certificate courses, there are more places than candidates whereas for Law and Medicine there are more candidates than places.

There are many aspects to be considered when discussing the Brazilian educational scenario, but in this article we will simply focus on the way in which the teaching professional speaks about him/herself. For example, in an interview study that was done with thirty-four public school teachers and an equal number of public school principals, Lemos (2009, p. 120) asked what caused these professionals to think of abandoning their profession. The three reasons that topped the list were: 1) the devaluation of the profession in society; 2) the violence and indiscipline of the students; 3) the low pay. In another interview study which resulted in a book entitled The Teacher as Hostage ( $O$ Professor Refém), Zagury (2006) came to the conclusion that the teacher is a hostage of not having enough time to fulfill everything that is required nowadays of this professional, of a macro system that does not work, of the indiscipline of the students in the classroom, and lastly of society itself. This book was based on 1.172 interviews with teachers from twenty-two states in Brazil.

Another research study consisting of interviews with the members of a Municipal District Administration and also with Coordinators in a local school, detected that the administration and the local school do not communicate effectively and that this causes frustration and discontent especially for the members of the local school (Rees \& Ferreira, 2012). As one Coordinator stated in an interview, "Another thing that makes things difficult is that the different departments don't speak the same language. One tells us to do things a certain way, a week later it's not that way anymore. Then there's a crisis because you've told the teacher to do things a certain way and then in a week you have to change" (p. 7) ${ }^{1}$.

The Coordinators also mentioned the students' lack of discipline: "The biggest problem is the lack of respect. Students tell us to [expletive deleted] with no hesitation. And the swear words!... They have no limits" (p. 13). When asked if the Coordinators could do anything about this, they said they try by calling the parents to the school:

We ask the mother to come and talk with us and she dumps her problems on us: she's separated; she works all day and doesn't have time to be with her children, her kids stay out on the street, or the husband is an alcoholic, in other words, family problems. The biggest problems aren't the kids, but the

1 All the translations have been done by the authors. 
families. The families aren't able to bring their kids up. So they throw the responsibility on the school. And the school doesn't have the means of teaching the student what he should have learned at home: respect. The student sees his father beat his mother, or has an alcoholic father or a drug dealer for a father and then the student gets so angry that he takes it out on us. And then what? (p. 14).

This quote shows that in a local context where the Coordinators were interviewed, there is a feeling that the role of the family in their children's upbringing has been transferred to the schools. We could say that this situation corroborates the idea that education is not an isolated process for it involves the individual in relation to the social group and the wider society (Morrison, 2008). The fact is that frustrations at all levels coupled with low pay have caused Brazilian teachers to decide to leave the teaching profession and find work elsewhere.

\section{The Forwardables}

A total of 12 forwardables were received, which can be divided into 4 main themes: Events in the classroom (4); Exhortation to the teacher (1); The teacher's worth in society (5); Criticism of the low salaries (2). Of the twelve, 3 were cartoons and the rest were in written text format. As it is not possible to analyze all the forwardables due to the required extent of the article, we have chosen to analyze the forwardables that were sent most frequently. Thus we will analyze four forwardables: one regarding events in the classroom, one regarding the exhortation to the teacher, one regarding the teacher's salary, and one regarding the teacher's worth in society. The themes overlap, but in each forwardable it is possible to detect a dominant theme.

\section{Cultural Domain and Critical Discourse Analysis}

For the purpose of analyzing these forwardables, we decided to combine two analytical perspectives that complement each other and can help elucidate how the forwardables are cultural artifacts and how they are inserted in discourse. In this way, we will use the concept of cultural domain as described by Spradley (1980) and the methodological principles of critical discourse analysis as discussed by Fairclough (2010).

As stated by Spradley (1980, p. 88), a cultural domain is "a category of cultural meaning that includes other smaller categories". In order to begin the analysis with this focus in mind, the following chart suggested by Spradley (p. 93) was used:

Table 1.

Cultural Domain Analysis Sheet

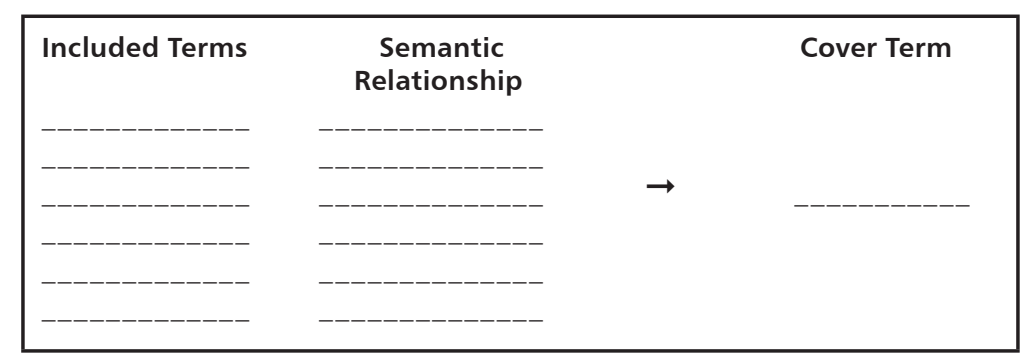

Source: Spradley (1980, p. 93) 
The Cover Term refers to the term that is under analysis. For example, if the teacher is the focus of the analysis in one of the forwardables, the term teacher would be inserted as the Cover Term. The domains are analyzed using semantic relationships such as: $X$ is a characteristic of $Y_{;} X$ is a reason for doing $Y ; X$ is a result of $Y$, and so on. Spradley $(1980$, p. 93) lists a total of nine semantic relationships, but allows for the use of others according to the focus of the analysis.

Using the Cover Term teacher and the semantic relationship $X$ is a characteristic of $Y$, it is possible to fill in the chart as follows:

Table 2.

Example of Cultural Domain Analysis

\begin{tabular}{ccc}
\hline Included Terms & Semantic Relationship & Cover Term \\
\hline$X$ & is a characteristic of & $Y$ \\
\hline$X$ & is a characteristic of & the teacher \\
\hline - Being tired & & \\
- Being overworked & & \\
\hline Authors' exemplification & \\
\hline \hline
\end{tabular}

Source: Explication of Spradley (1980)

The result is read as: being tired is a characteristic of the teacher; being overworked is a characteristic of the teacher. Through this analysis, it is possible to understand the meaning that a certain cultural group assigns to specific terms. As Spradley states: "Cultural descriptions can be used to oppress people or to set them free" (1980, p. 17). Consequently, to understand the cultural meaning is not just to add to a bank of scientific knowledge, but is a means of understanding how people of a certain cultural group give meaning to their lives, and accordingly be able to discuss these meanings as situated within society and its structures of power and meaning.

In its turn, critical discourse analysis focuses on how language and discourse relate to power and social change. Thus the sense of critique that guides this research field is that which highlights the need to unveil, contest and rearticulate discourses that promote inequalities in particular and/or in larger contexts. As Fairclough puts it, the sense of critique used by critical discourse analysis

... focuses on what is wrong with a society (an institution, an organization etc.), and how 'wrongs' might be 'righted' or mitigated, from a particular normative standpoint. Critique is grounded in values, in particular views of the 'good society' and of human well-being and flourishing, on the basis of which it evaluates existing societies and possible ways of changing them (2010, p. 7)

Given that critical discourse analysis includes analysis of texts in their different semiotic forms (verbal messages, body language, visual images, and sounds), its main purpose is to explore "dialectical relations between discourse and power, and their effects on other relations within the social process and their elements" (p. 8). One of the central aspects of this purpose is the concept of ideology: "ways of representing aspects of the world, which may be operationalized in ways of acting and interacting and in 'ways of being' or identities, that contribute to establishing or sustaining unequal relations of power" (p. 8). However, the author considers that 
ideologies can be contested and rearticulated, especially when they represent or explain the world improperly.

Following these premises and based on a dialectical-relational approach to textual analysis, Fairclough (2010, p. 235) proposes a methodology comprised by four stages: 1) Focus upon a social wrong ${ }^{2}$, in its semiotic aspect; 2) Identify obstacles to addressing the social wrong; 3) Consider whether the social order "needs" the social wrong; and 4) Identify possible ways past the obstacles. Stage 1 is about creating "a better understanding of the nature and sources of social wrongs" (p. 235). Stage 2 aims at approaching the social wrong indirectly "by asking what it is about the way in which social life is structured and organized that prevents it from being addressed" (p. 237). Stage 3 is about considering "whether the social wrong in focus is inherent to the social order, whether it can be addressed within it, or only by changing it" (p. 238). And finally, Stage 4 aims at identifying "possibilities within the existing social process for overcoming obstacles to addressing the social wrong in question" (p. 239).

Together with the discussion of cultural domains (Spradley, 1980), and how meanings are assigned, these four methodological stages of critical discourse analysis will be considered in our further analysis, due to the fact that the forwardables represent culturally situated practices composed of different semiotic forms (in this case, verbal messages and visual images).

\section{Forwardable 1 - Events in the Classroom}

\section{Forwardable - What Grades are These?}

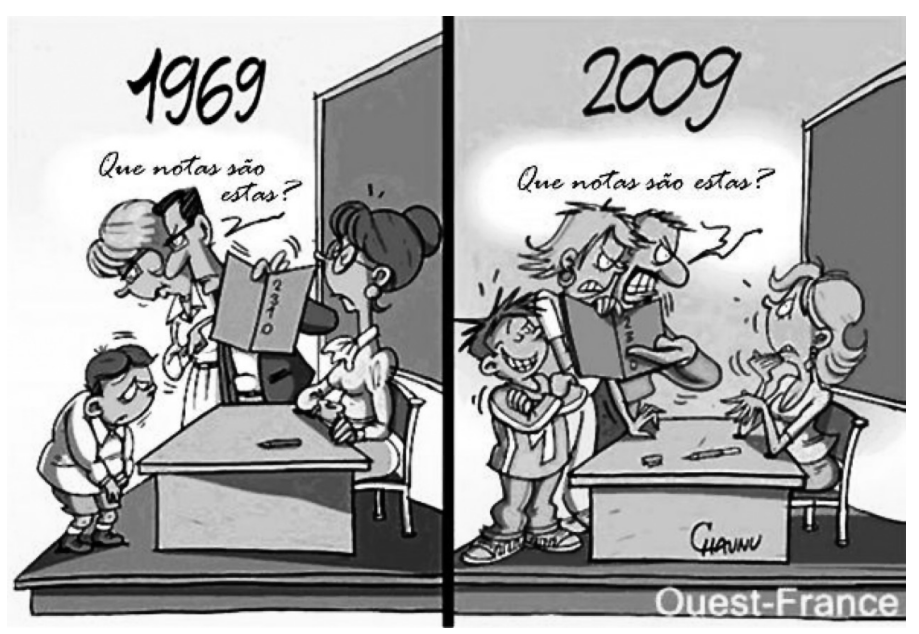

Source: Chaunu (2009)

This cartoon has arrived in the authors' email box consistently since 2009. It was sent on in 2011 by several people with notes to the effect that it was not 2009 anymore, but the scenes depicted continued to be true. It has since been received with the second date changed to 2013. In total, it has been received 10 times.

2 According to Fairclough (2010, p. 235), social wrongs "can be understood in broad terms as aspects of social systems, forms or orders which are detrimental to human well-being, and which could in principle be ameliorated if not eliminated, though perhaps only through major changes in these systems, forms or orders. Examples might be poverty, forms of inequality, lack of freedom or racism". 
The cartoon, created by Emmanuel Chaunu and published for the first time in the online newspaper Ouest France, began to circulate on blogs in Brazil in June 2009, appearing in French on the blog owned by Professor Elias Rodrigues (www.eliaswordpress.com) on June $13^{\text {th }}$. He states that he received the cartoon in a post from his friend and colleague Professor Luis Carlos Assis lasbeck of the Universidade Católica de Brasília. On June 17 ${ }^{\text {th }}$, the blogger Sarico (http://www.blog-br.com/sarico) mentions receiving an email with this cartoon. He uses the description of the cartoon to discuss how the Brazilian classroom has changed over the last 30 years. He does not mention the fact that the cartoon was first produced in France focusing on the French classroom. On the $8^{\text {th }}$ of July 2009, the cartoon appears already translated into Portuguese on the blog Direito e Arte - Música e Caricatura (Law and Art - Music and Cartoons - www.direitoearte.blog/ lemonde.fr).

The cartoon depicts a woman teacher which concurs with the feminization of the teaching professional in Brazil (Gatti, 2009, p. 10). It has honed in on a widespread societal angst by depicting the changes in the power relations within the classroom. Using the concept of cultural domain (Spradley, 1980), it is possible to analyze the 1969 drawing of the teacher in the following way:

Table 3.

Forwardable 1 - Cultural Domain Analysis 1

\begin{tabular}{c|c|c}
\hline Included Terms & Semantic Relation & Cover Term \\
\hline X & is/are the characteristic(s) of & the teacher \\
\hline - Upright posture with shoulders back & & \\
- An impassive facial expression with closed eyes & & \\
- Hands resting on the table with one curled into a fist & & \\
- Small lines drawn above the head depicting confidence & & \\
\hline \hline
\end{tabular}

Source: Own elaboration

From this posture, it is possible to conclude that the teacher is confident of her position of power, sure of her place in that setting and of the possibility of being heard by parents. The cultural domain of the teacher is one of confidence and of empowerment. The teacher's voice is heard. The parents turn away from the teacher and address their child for explanations. On the other hand, the teacher in 2009 has the following characteristics:

Table 4.

Forwardable 1 - Cultural Domain Analysis 2

\begin{tabular}{c|c|c}
\hline \multicolumn{1}{c|}{ Included Term } & Semantic Relation & Cover Term \\
\hline $\mathrm{X}$ & is/are the characteristic(s) of & the teacher \\
\hline - A curved posture with shoulders bent away from the parents & & \\
- A worried facial expression with eyes wide open & & \\
- Elbows resting on table with one hand at the mouth & & \\
- Small lines drawn in front of the face depicting worry & & \\
\hline \hline
\end{tabular}

Source: Own elaboration

The teacher in this section of the cartoon does not have control over her own classroom. Power has been transferred from the teacher to the 
demands of the child shown in the figures of the parents who turn toward the teacher with looks of anger demanding an explanation. Thus the cultural domain embodied in the word teacher is no longer the same as that in 1969. The teacher now is powerless, a figure that is harassed and from which obedience to the wishes of the family is expected.

The cartoon in France was a pictorial lead in to a discussion about whether or not parents had the right to question the teacher's authority. In Brazil, on the other hand, the cartoon was not forwarded as a gambit for a discussion about whether society should take a direction that could end up disempowering the teacher. Rather, the cartoon was sent on as a pictorial depiction of what has inexorably happened to the teacher, a systematic disempowerment leading to a culturally depreciated role in society. The forwarders, who were all teachers, sent on the cartoon as an expression of how they felt as professionals in the field of education. In this way, the cartoon became personalized, a visual depiction of how the ones who forwarded it saw their own condition in Brazilian society. The forwarding became an intentional act of identification with and participation in an evaluation of their cultural role. It also became a protest against that imposed role as comments in the body of the emails that accompanied the forwardable attested: "How much longer can we put up with this?"; "This is our sad reality!"; "We laugh [at our reality] in order not to cry".

Considering the methodological principles of critical discourse analysis proposed by Fairclough (2010), we can see that the social wrong depicted in the cartoon is the dramatic disempowerment of the teacher as a professional throughout the last four decades, which in our point of view is also related to the changes which have occurred within the same period of time concerning the role of parents in their children's upbringing. This social wrong can be observed both in the visual images and in the verbal message of the cartoon. The main obstacle to addressing the disempowerment of the teacher before her/his students, their parents and the whole society is that this position has gradually become naturalized and trivialized in Brazil. In other words, most Brazilians, including parents, students, teachers and politicians, tend to consider it a mere reflection of our culture that cannot be contested and changed. This perception leads us to think that the social wrong in focus is somehow "necessary" for Brazilian social order. Thus the only possible way past the obstacles we can see is to build and spread critical analysis of this situation so that teachers start to refuse directly and/or indirectly the role and the position they have been forced to embrace. The forwarding of the emails is an attempt to protest the position, yet the sense of powerlessness to effect change seems to be an underlying motif.

\section{Forwardable - Exhortation}

Teacher with pride.

Teacher with pride.

If a doctor, a lawyer or a dentist had at the same time 45 people in his/her office or consulting room, all with different needs, and some not wanting to be there, and the doctor, the lawyer or the dentist had to treat them all with a high level of professionalism for ten months, then they might get an idea of what the teacher's work in the classroom is like.

If you are a TEACHER - BE PROUD.

(Forwardable received six times)

Email forwardable with no specified authorship 
This text does not have a specific author nor a site of publication (blog, opinion piece, social network etc.), although it is clearly grounded in a discourse which defines teachers as deserving admiration due to the hard work they undertake.

The forwardable begins with the exhortation, "Teacher with pride" repeated twice. It is possible to state that an exhortation for pride occurs when a group feels that it does not have social prestige. Diniz-Pereira (2011, p. 47) points out that the social representation of the teaching profession "is strongly marked by a feeling of inferiority, mediocrity, and incapacity". In the forwardable the professions that are contrasted to the teacher are doctor, lawyer, and dentist, professions that are socially more prestigious. This prestige can be perceived in the higher salaries that these professionals make, and in the fact that the university courses for these professions are the ones that are the most sought after. In contrast, the teaching certificate courses are going through a crisis with more places than candidates. At our university, there are 500 places that are not filled annually in the teaching certificate courses. Fewer and fewer people want to be teachers.

The argument in the forwardable in favor of the teaching profession is to show the characteristic of what the teacher has to face daily and to indirectly contrast this to the other three professions that are mentioned. Thus, using Spradley (1980), it is possible to set up the following cultural domain characterizing the teaching profession:

Table 5.

Forwardable 2 - Cultural Domain Analysis 1

\begin{tabular}{c|c|c}
\hline \multicolumn{1}{c|}{ Included Term } & Semantic Relation & Cover Term \\
\hline \multicolumn{1}{c|}{ X } & is/are the characteristic(s) of & the teaching profession \\
\hline - Dealing with 45 people at a time & & \\
- Dealing with the same people for 10 months & & \\
- Dealing with people who don't want to be in class & & \\
- Dealing with them in a professional way & & \\
\hline \hline
\end{tabular}

Source: Own elaboration

This contrasts to doctors, lawyers, and dentists who only have to deal with one person at a time and intermittently, not steadily for ten months. Additionally, most clients of the three professions have personally sought out the professional services even if they might not enjoy the experience. This contrasts to the teacher who has people in the classroom who have been forced to be there by society and often see no value in learning history, English, algebra and so on.

"A high level of professionalism" is also a cultural domain which the reader has to elaborate, but can have the following characteristics:

Table 6.

Forwardable 2 - Cultural Domain Analysis 2

\begin{tabular}{l|l|l}
\hline \multicolumn{1}{c|}{ Included Term } & Semantic Relation & Cover Term \\
\hline \multicolumn{1}{c|}{$\mathrm{X}$} & is/are the characteristic(s) of & professionalism \\
\hline - Being polite & & \\
- Being calm & & \\
- Being organized & & \\
- Being firm & & \\
- Being dedicated & & \\
\hline \hline
\end{tabular}

Source: Own elaboration 
Hence the teacher, in the face of a difficult situation characterized by opposition, is professional. Implied is the fact that the teacher has a heavy load, much heavier than the other three professions, yet it is these professions that receive more social respect.

Drawing on Fairclough (2010), we can see that the social wrong depicted in this forwardable is the perception that the teacher is professional because s/he knows how to masterfully overcome the difficulties of her/his daily routine at schools. The main obstacle to addressing this social wrong in Brazil is, in our point of view, the indirect (and sometimes direct) acceptance of teachers' bad working conditions, which leads to the point of teachers themselves assuming that they are professionals because they can, for instance, attend to 45 different people at the same time under difficult circumstances. And we believe that this "ability" is something to be contested, not to be celebrated. Like the previous forwardable, this one allows us to consider that the social wrong in focus is somehow "necessary" for Brazilian social order, which has always tried to postpone structural changes in the teaching career, especially regarding the teacher's salary and working conditions. Thus one possible way to overcome the obstacles is to think more carefully and more critically about the working conditions which were historically and culturally imposed on teachers in Brazil, so that we can elaborate local strategies to change the larger educational structure.

\section{Forwardable - The Teacher's Worth in Society}

We don't need EDUCATION

We don't need TEACHERS

After all...

Why be a FIRST WORLD country if we're fine the way we are...

Ronaldinho Gaúcho (soccer player): 1.400.000.00 Reais a month

Honored at the Brazilian Academy of Letters - HE'S ERUDITE

Tiririca (a humorist elected to Congress): 36.000 .00 Reais a month besides emoluments

Member of the Comity of Education and Culture in the Congress ... AS THE GAUCHOS (Brazilians from the southernmost state) SAY - TCHÊ . . HOW ABOUT THAT?

TRANSLATING, THE CLOWN'S SALARY WOULD PAY 30 TEACHERS AND FOR THOSE WHO SAY EDUCATION ISN'T IMPORTANT, HIRE TIRIRICA TO TEACH YOUR KID.

Moral of the Story:

The teacher doesn't make much because they are only good for teaching us useless things like: Reading, writing and thinking.

Suggestion:

Change the school curriculum and offer new subjects:

- Physical Education: Soccer;

- Music: Sertaneja, Pagode, Axé (pop styles of Brazilian music);

- History: Great Personalities of Brazilian Corruption, Biography of the Heroes of

Big Brother TV show, The Evolution of the Thoughts of Celebrities;

- Math: Multiplication of Fraudulent Campaign Money;

- Portuguese and Literature: ??????? What for?????????

- Biology, Physics and Chemistry: Excluded because they're too complicated.

This is just great or do you want more??!!!

THIS IS OUR BRAZIL

(Forwardable received 7 times)

Email forwardable with no specified authorship 
The authorship of this email forwardable is anonymous, however the textual voice or narrator is someone linked to education, probably a teacher. This person is also angry at the state Brazilian society is in and demonstrates this anger in the ironic tone used to propose actions that are obviously the opposite of what s/he thinks is good. The text is written from within Brazilian society as the narrator uses the pronouns "we" and "our" marking herself/himself as a member of this society. As a result, the idealized reader to whom the text is directed is also a member of Brazilian society and is included in the "we" and the "our" pronouns.

Two famous Brazilians are mentioned: Ronaldinho Gaúcho and Tiririca. Ronaldinho Gaúcho is a football star who plays for the Flamengo team and for the Brazilian national team. He along with the coach of the Flamengo team were invited to a commemorative dinner at the Brazilian Academy of Letters, and both received the Machado de Assis Medal. According to the press releases, they were invited in order to help celebrate the centenary of the birth of the author José Lins do Rêgo who was an ardent Flamengo fan. Tiriri$\mathrm{ca}$, in his turn, is a television comedian that got elected to Congress as a result of a protest vote. Before he was able to assume his congressional seat, he had to take a literacy test to make sure he knew how to read and write. He is now part of the Education and Culture Committee in the Congress, the argument being that he is part of popular culture and thus will have contributions to make to that sector.

Ronaldinho Gaúcho and Tiririca have not had any direct connection with the Brazilian education system. Both came from poor families, Tiririca has had very little formal education, and both were able to rise socially because of their particular talents and the importance given to these types of talents in Brazilian society. Soccer is a revered sport in Brazil and the best players soon become millionaires. Television culture with its slapstick comedy is a popular venue of entertainment and its proponents soon become famous and well-off. Yet, in spite of the fact that neither one has ever been associated throughout their professional lives with educational concerns, both have now become connected to groups that represent or in some way deal with education and literate culture. To the author of the forwardable, this is an irony present in Brazilian public life as can be inferred by the use of capital letters indicating indignation, "TCHÊ - HOW ABOUT THAT!", and even in the reference to Tiririca as "THE CLOWN" (o palhaço) and not as "the humorist".

Analyzing the meaning of the word "palhaço" in Brazilian Portuguese and culture, it is possible to set up the following cultural domain chart:
Table 7.

Forwardable 3 Cultural Domain Analysis

\begin{tabular}{c|c|c}
\hline Included Term & Semantic Relation & Cover Term \\
\hline$X$ & $\begin{array}{c}\text { is/are the } \\
\text { characteristic(s) of }\end{array}$ & palhaço \\
\hline - Being a buffoon & & \\
- Being a stooge & & \\
- Being a fool & & \\
- Being uneducated & & \\
- Being impolite & & \\
- Being irrational & & \\
\hline \hline
\end{tabular}

Source: Own elaboration

On the other hand, the word humorist does not carry any of these pejorative meanings. Thus the author of the text deliberately insults Tiririca by choosing the word "palhaço" to refer to him.

Considering the principles of critical discourse analysis (Fairclough, 2010), we can observe that the main social wrong depicted in this forwardable is the attempt to call attention to the problems of a specific professional group (teachers) by devaluing other professionals (soccer players and humorists). One of the central problems in addressing this social wrong is that the supposed inferiority and unworthiness of professionals whose functions are not directly associated with formal education, intellectual work or erudite culture has also been naturalized in Brazil. This can be observed in the fact that most people tend to read this forwardable and totally agree with its message, that is, they find it normal to highlight the worth of teachers by highlighting the unworthiness of soccer players and humorists. Like in the previous forwardables, we believe that the social wrong depicted in this one is to some extent "necessary" for the social order in Brazil, which "needs" to establish a competition between groups that are symbolically diminished in the Brazilian imaginary in order to reinforce and naturalize their symbolic and material (in the case of teachers) inferiority. Hence one possible way past the obstacles is, in our point of view, to highlight the need to fight for respect and dignity without underestimating the talent and the worth of others.

Another point that we consider important to note is that, throughout the entire forwardable, there is the evaluation of Brazil as not being a first world country. It can be deduced that to the author of the email, a first world country is a country that values education and teachers. The statements "We don't need edUCATION", "We don't need teachers", "Why be a FIRST WORLD country if we're fine the way we are" are obviously the opposite of what he considers important, and thus are ironic. This tone reaches its apex in the section with the suggestions as to the school 
curriculum. Through this list, it is possible to infer that the characteristics of Brazilian society include corruption scandals ("Great Personalities of Brazilian Corruption"), bad TV shows ("Big Brother TV show"), bad music ("Sertaneja, Pagode, Axé"), a reductionist view of sport (only soccer), and a rejection of anything complex ("Biology, Physics, Chemistry - Excluded because they're too complicated"). The low moral and cultural level of Brazilian society is linked to the devaluation of teachers in society because "they are only good for teaching us useless things like: Reading, writing, and thinking".

This forwardable specifically criticizes Brazilian society, but creates a contrast to other unnamed places (first world countries) that apparently are not in the same situation as Brazil due to the fact that they value teachers. These places are posited as being the opposite of Brazil. In this way, a sense of Brazil losing out on the large scale of the world stage is developed. Brazil is doomed to be second rate unless it changes and begins to value teachers and education. Hence, the cultural meaning assigned to Brazil is one of inferiority. There is no criticism offered of the discourse of binary positions such as inferior/superior and Third World/First World.

\section{Forwardable - Teachers' Salaries}

Today we are going to pretend to be a math teacher. I'm going to give you some math problems to solve

\section{Problem \# 1}

A teacher works 5 hours a day, 5 classes with 40 students each. How many students will s/he attend a day?

Answer: 200 students a day.

If we consider 22 work days. How many students will s/he attend a month?

Answer: 4.400 students a month.

Let's imagine that no student misses class (hahaha) and that each of them decides to pay the teacher the money to buy some popcorn: 80 cents a day. How much will the teacher make a day?

Answer: 160.00 Reais a day.

If we consider 22 work days. How much will the teacher make a month?

Answer: At the end of the month the teacher will make 3.520,00 Reais.

Problem \# 2

The wage level is 1.187 .00 Reais for a teacher to attend 4.400 students. How much does the teacher make for each student attended?

Answer: Aproximately 27 cents a month.

(wow, we're worth less than a bag of popcorn)..

(Forwardable received three times)

Email forwardable with no specified authorship

In order to understand the forwardable, it is necessary to know how the Brazilian school system works. It is divided between public and private schools. In the public system there are municipal schools that teach up to the equivalent of the eighth year of schooling and the state schools that teach the equivalent of high school. The public schools are attended by lower middle class and working class students. A characteristic of the middle class is to send their children to private schools in search of an education that will guarantee a better future for them and access to public universities which are the best higher education institutions and are tuition free. Public schools are considered to have a lower educational standard due to the overcrowded classrooms and in some cases the poor infrastructure of the schools. 
In addition to the municipal and state schools, there are also federally run public schools. They are a minority and are linked to the federal universities and are the location in which pre-service trainees do their practice teaching. There are also federally run technical schools. The federal public schools are considered to offer a higher level of education than the other types of public schools. This is a result of the fact that many teachers of the federal public schools have post-graduate degrees along with better salaries and also because the federal schools have a better infrastructure.

The length of a Brazilian school day period is half a day. Thus one school building can have three different school periods. The morning one runs from 7 a.m. to 12 a.m., the afternoon from 1 p.m. to 6 p.m., and the night one from 7 p.m. to 11 p.m. Each period can have a different school principle and staff and each period attends different types of students. For example, the night period usually has older students who have dropped out of school and have come back to get their formal education. They are people who come to school already worn out by a long workday. Many of the women bring their children with them to class. The Federal Government has recognized this fact and has created the EJA Program (Educação para Jovens e Adultos - Education for Young People and Adults).

In 2008, Federal Law number 11.738 was passed which established a wage level for public school teachers, consequently, no municipality or state could legally pay wages below this level. The wage level mentioned in the forwardable is the one established for 2011. It has since been raised. It is important to point out that the wage level is extremely low and many teaching professionals teach in the three periods available - morning, afternoon, and night - to make enough money to live.

The forwardable considers a teacher that is teaching during one school day period, approximately 5 hours a day. Using a cultural domain chart, it is possible to analyze the bag of popcorn:

Table 8.

Forwardable 4 Cultural Domain Analysis

\begin{tabular}{c|c|c}
\hline Included Term & Semantic relation & Cover Term \\
\hline$X$ & is/are a characteristic(s) of & a bag of popcorn \\
\hline - Being a snack, not a meal & & \\
\hline - Being the cheapest snack & & \\
\hline - Being worth 80 cents & & \\
\hline Authors' analysis & & \\
\hline
\end{tabular}

Source: Own elaboration

The message is obvious: economically the teacher is worth less than a bag of popcorn, the cheapest snack possible. Within the present capitalistic society, the teacher is worth almost nothing: "wow, we're worth less than a bag of popcorn". Implicit in this line is a sense of the powerlessness of the teacher within Brazilian society. This in turn is manifested in the low salaries of the profession. The teacher is needed and as mentioned previously there is a deficit of teachers, but the economic recognition of the importance of this profession has not yet occurred.

Drawing on Fairclough (2010), it is possible to observe that the social wrong depicted in this forwardable is the extreme low wage paid for 
teachers in Brazil, which reflects the position of this professional group within Brazilian culture and imaginary. Relating this fact to the larger society and to the history of Brazil, we can say that the main obstacle to addressing it is that the devaluation of teachers, which is materially expressed in their low salaries, has also become a naturalized situation in Brazilian society. There is, as well, an ideology in the country according to which teachers have to work for love and not for money, as they knew how much they would be paid for doing their job. Like the others, this forwardable leads us to assume that the social wrong it depicts is somehow "necessary" for Brazilian social order, especially because the money that could be paid for teachers can be "applied" to other areas - considered more important than education. In brief, the less the governments pay for teachers, the more they can invest in other public and private projects which hardly ever benefit the whole society. Thus we believe that one possible way past the obstacles is to engage in public debates regarding the worth and complexity of the teaching career, highlighting its role in the transformation of the social order.

We consider that this forwardable served as a way of uniting a professional group by focusing on a topic that has a consensus, that is, teachers are badly paid and not valued within Brazilian society. Teachers might disagree about many things, but the low wages is not one of them.

\section{Concluding Remarks}

In our point of view, the email forwardables that were analyzed in this article show another aspect of group identity beyond that of professional activities which is a sense of occupying a place of low social prestige. It is a group that does not feel it is a part of the power groups within society and feels that it is not respected in monetary terms and is not respected as a competent professional by administrators, parents or students.

The forwardables were sent from teacher to teacher and were used as a means of registering a protest against the position of the teacher in society. This protest was sent to fellow teachers for the most part, and through this helped create a sense of identity and rehearsed the anxieties of the teacher cultural group in Brazil, the anxieties regarding low wages, student disrespect, problems with parents, and the place of low social prestige. The forwardables speak for those that are outside the power groups where the wages and the school administrative rules are decided. The forwardables, therefore, by being sent on from teacher to teacher in a continuous chain, become a form of social cohesion of this particular group. This fact corroborates the sense of critique suggested by Fairclough (2010) insofar as it unveils what is wrong with a society and simultaneously works as an alternative to mitigate this social wrong from a situated perspective, that is, a perspective rooted in socio-historical boundaries.

In conclusion, it is possible to say that the forwardables act as a link that represents the concerns of a certain group and that this link via discourse and the internet is capable of creating larger and larger circles of those who feel bound together by specific concerns. The forwardables become a voice through which the teacher community articulates its concerns, its frustrations and its sense of powerlessness regarding the changes in power relations in the classroom, the lack of prestige in society, and the low salaries.

In a more practical instance, it is possible to use forwardables such as these to discuss with future and working teachers the discourse practices 
that surround the cultural identity of the profession and how these emanate from the popular imaginary regarding the teacher and the teaching profession in Brazil. After all, critical thinking might be one of the most effective alternatives we have to produce counter discourses about and for the teacher community in our country.

\section{About the authors}

Dilys Karen Rees teaches in the Faculdade de Letras at Universidade Federal de Goiás. At the undergraduate level, she teaches language and literatures of English and at the post-graduate level she teaches Intercultural Aspects of the Classroom researched through Ethnographic Studies.

Marco Tulio de Urzêda-Freitas teaches English in the Centro de Línguas of the Universidade Federal de Goiás. He also teaches Critical Language Learning and Queer Literacies in English teacher education courses in Goiânia.

\section{References}

Calvo, A. C. (2008). O uso indevido do correio eletrônico no ambiente de trabalho. Brasilia, Brazil. Retrieved from: http://www.conteudojuridico.com. $\mathrm{br} /$ ?artigos\&ver $=2.21537 \&$ seo $=1$

Carvalho, T. L. de (2010). Ensino de espanhol auxiliado por emails: Depoimentos de alunos que vivenciaram esta experiência no núcleo de línguas da Universidade Federal do Ceará. Hipertextus, 5. Retrieved from: http:// www.hipertextus.net

Chaunu, E. (2009). Ouest France. Retrieved from: http:// www.ouest-france.fr

Deaux, K. (2001). Social identity. In: J. Worrell (Ed.). Encyclopedia of women and gender (pp. 1-9). San Diego: Academic Press. Retrieved from: http:// www.utexas.edu/courses/stross/ant393b_files/ ARTICLES/identity.pdf

Diniz-Pereira, J. E. (2011). O ovo ou a galinha: A crise da profissão docente e a aparente falta de perspectiva para a educação brasileira. Estudos RBEP, 92, 34-51. Retrieved from: http://rbep.inep.gov. br/index.php/RBEP
Fairclough, N. (2010). Critical discourse analysis: The critical study of language [1995]. Harlow: Pearson Education Limited.

Gatti, B. (Coord.) (2009). Atratividade da Carreira Docente no Brasil. Fundação Carlos Chagas. Retrieved from: http://revistaescola.abril.com.br/pdf/ relatorio-final-atratividade-carreira-docente.pdf

Lemos, J. C. G. (2009). Do encanto ao desencanto, da permanência ao abandono: O trabalho docente e a construção da identidade profissional. (Unpublished doctoral thesis). Pontifícia Universidade Católica, São Paulo. On-Line: http://revistaescola.abril.com.br/gestao-escolar/tese_jose_ lemos.pdf

Marcuschi, L. A., \& Xavier, A. C. (2005). Hipertexto e gêneros digitais: Novas formas de construção de sentido ( $2^{\text {nd. }}$ ed.). Rio de Janeiro: Lucerna.

Mapa da Exclusão Digital (2003). BNDES. Retrieved from: http:// www.bndes.gov.br.

MEC - Ministério da Educação e Cultura (2008). Falta de professores preocupa especialistas. Retrieved from: http:// www.portal.mec.gov.br

Morrison, K. (2008). Educational Philosophy and the Challenge of Complexity Theory. In: M. Mason (Ed.). Complexity theory and the philosophy of education (pp. 16-31). Chichester: Wiley-Blackwell.

Paiva, V. L. M. O. (2001). A www e o ensino de inglês. Revista Brasileira de Linguística Aplicada, 1, 93-116.

Souza, M. A. A. de (2005). Email e o ensino de língua inglesa. Intercâmbio, 14, 1-11. Retrieved from: http://revistas.pucsp.br/index.php/intercambio/ article/view/3947.

Rees, D. K., \& Ferreira, H. B. (2012). Unidade regional e escola: Visões conflitantes - um estudo de base etnográfica. Ensino em Re-Vista, 19, 409-424. Retrieved from: http://www.seer.ufu.br/index. php/emrevista/issue/view/731.

Spradley, J. (1980). Participant observation. Fort Worth: Harcourt Brace College Publishers.

Zagury, T. (2006). O professor refém. Rio de Janeiro: Record. 